\title{
Sciendo
}

\section{THE USE OF THE EDUCATIONAL FUNCTION OF MEDIA IN FOREIGN LANGUAGE TEACHING Kinga Bajorek', Sławomir Gawroński²}

\begin{abstract}
The use of mass communication in the field of foreign language teaching is not a new phenomenon, because traditional media have been in use in this area for a few decades. Nowadays, however, several tendencies confirming the scale of this phenomenon can be observed. Mass media, and new media in particular, are used both in the process of self-education and as an important tool used by foreign language teachers. Technological progress, the communication revolution, the spread of the Internet, and the development of new media and mobile technologies offer modern and more effective methods of language education. This article reviews the conditions relating to the relationship between mass media and language learning, taking into account the possibility of using one of the key functions of mass communication, namely its educational function. The authors, using literature analysis, defined and analyzed the causes of specific symbiosis between media tools and technologies as well as the methodology used in the field of foreign language teaching.
\end{abstract}

Keywords: mass media, foreign language teaching, media education.

In modern reality, foreign language skills have become a necessity. Linguistic competence is not only an instrument that facilitates communication, but also allows you to acquire information necessary for effective functioning in a dynamically changing reality, or exploiting the opportunities that the labor market brings with it [Kleban, 2014, p. 5]. This assumption confirms the result of the European Language Competence Survey, in which the students confirmed a positive way of perceiving the relationship between fluency in foreign languages and their personal life, issues concerning getting a future job, and further education. At the same time, $80 \%$ of respondents felt that the most important role for them in their future life was English. What is important, a large part of the respondents stated that mass media have a big influence on shaping their language proficiency [UPUE, 2012, pp. 105-106]. Modern foreign language education is increasingly using the educational functions of mass media, which are present both in an organized system of education and in self-education.

\section{THE KNOWLEDGE OF FOREIGN LANGUAGES AS A KEY COMPETENCE}

\footnotetext{
Department of English Philology, University of Information Technology and Management in Rzeszow; e-mail.: kbajorek@wsiz.rzeszow.pl

$2 \quad$ Associate Professor in Chair of Media, Journalism and Public Relations. Mass media and political scientist. Dean of the Faculty of Administration and Social Sciences at the University of Information Technology and Management in Rzeszow. E-mail: sgawronski@wsiz.rzeszow.pl.
} 
The eight key competences listed in the European Parliament Recommendation of 18 December 2006 on key competences in the lifelong learning process included, inter alia, the ability to communicate in foreign languages. The definition of this ability, formulated in the aforementioned legal act, assumes that it is based primarily on a similar level of skills as the ability to communicate in the mother tongue. It allows you to understand, articulate and express people's concepts, facts, thoughts, currently experienced emotional states, in written and oral form, that is: listening, fluent speaking, reading and writing. These activities take place in adequate cultural and social contexts, depending on the free will or current needs of the individual. Competences in the field of communication in foreign languages can also be transferred into mediation as well as understanding cultural differences. The assessment of the fluency of the level of skills by a particular person is diversified while analyzing the four basic language competences, namely: writing, reading, speaking and listening comprehension. It is also dependent on certain factors that are the result of a personal plan resulting from the cultural and social background, as well as a closer and further environment, and above all the needs or areas of interest of a given unit [UOPWE, 2007, p. 5].

A number of theoretical assumptions referring to the teaching process is mentioned in the methodical literature on foreign languages. The teacher has a whole spectrum of methods designed to effectively stimulate the student's motivation and activation processes. As Ewa Łoś and Alina Reszka correctly note, when analyzing the existing proposals, one can get the impression that all didactic possibilities have already been used. However, the authors emphasize that there is not one universal and effective method of teaching that can be used in all circumstances. The teacher himself adjusts the learning cycle based on his own judgment and interpretation. This is due to the fact that methodological goals, the most effective methods of teaching a foreign language are selected due to the teacher's conviction [Łoś, Reszka, 2010, p. 5].

In the last few decades, the model of foreign language teaching has changed fundamentally, evolving along with a change of views on the very concepts of the teaching process as well as the mechanisms of human learning. The consequence of this phenomenon was also the change in the attitude of teachers who, having acquired new knowledge, began to introduce innovative methods and teaching instruments [Targońska, 2009, p. 11]. Glottodidactics was provided by effective teaching instruments by the media revolution. The authors, dealing with the broadly understood research of learning and teaching foreign languages processes in practice, describe these teaching tools as educational media [Zarzycka, 2014, p. 321]. Foreign language teachers have the opportunity to select effective teaching methods and instruments. In this respect, there is a wide range of possibilities, ranging from proven, traditional programs to copyright projects. As M. Trawiński notes, curricula do not impose any rigid barriers for teachers. According to the author, the most important is teacher's preparation for skilful evaluation and then the choice of methodological tools [Trawiński, 2009, p. 312]. Hanna Komorowska states that the purpose of teaching a foreign language is to give the student communication skills. It can be observed in the effective acquisition and transmission of information, both in pronunciation and in writing, adequately to the existing situation. Linguistic competence, through the correct structure of sentences in more complex forms is the developed form of the above. "Competent user" in the course of a language learning process masters the following subsystems: phonic, graphic, lexical and grammatical one [Komorowska, 2005, pp. 9-10].

\section{COMMUNICATION IN GLOTTODIDACTICS}

Teaching has the character of intentional actions, which aims at evoking the learning process. At the level of didactic communication, the teachers and the students take on the roles of senders and recipients of information. The basic condition for the success of effective communication is the interpretation of the message, which becomes 
consistent with the intentions of the sender and his/her recipient [Wiesner, 2005, p. 8].

The term "communication" originates in the Latin "communicare", which means participating in certain activities, actions, or sharing information with someone. Tomasz Goban-Klas notes that the communication process is carried out at many levels, takes various forms, through the use of numerous instruments. The basic condition for the existence of communication is in each case the presence of at least two of its participants. In the discussed process, they play the roles of senders or receivers using common, understandable for all parties codes, that is, contractual marks in the form of a message. The author emphasizes that the code and message function objectively, causing a phenomenon described by Goban-Klas as "intersubjective cognition". In the communication process, the participants also have the ability to change roles, but in terms of a specific moment they perform designated roles [Goban-Klas, 1999, p. 9]. Hein Retter believes that communication should be characterized by the presentation and subsequent transfer of information from the level of a system of language commonly used, to the level of a system of a technical nature. This also applies to the migration between individual groups of logical systems. The communication function is primarily visible in giving meaning to verbal messages, although words cannot, of course, be classified as an exclusive data of communication model. The communication process is carried out between individuals, organizations and communities functioning in a society [Retter, $2005, \mathrm{pp} .11-12$ ]. The need for communication is a natural feature of every human being, due to the existence in a community in certain forms. It takes place in a strictly defined situation, which is determined by strictly defined factors. Three essential elements are necessary for the communication process to occur: the sender of the message, its recipient and the communication channel. The causes of interpersonal communication are also important on the individual as well as a collective (social) level. For each conversation, a specific purpose of the sender and the recipient is performed. This causes that the conversation actually gains sense as a result of the information gap, which can be described as a disproportion on the level of knowledge in a given field [Komorowska, 2009, pp. 74-75].

The communication process is an element of interest in various fields of knowledge. From social communication, political communication, media, interpersonal, intercultural to psychological one. However, in the contemporary culture and science, visual communication is becoming more important [Kawka, 2015, p. 13]. In the area of mass media development, it can be noted that visual communication uses means with functions and tasks limited to providing information as well as persuasive and educational purposes. They do not work independently, they form a catalog that, along with the text, allows to achieve the intended goal [Kawka, 2015, p. 13]. In the modern world, people have been growing up surrounded by the achievements of Information technology. It is virtually impossible for an individual not to interact with digital media which can be compared to the most important elements of the natural environment. It is the duty of every contemporary foreign language teacher to adapt to the contemporary conditions of glottodicatics [Garwol, 2017, p. 51]. Anna Gębalska-Berekets believes that in the era of dynamic changes taking place in the modern world, one should skillfully use the roles and functions of the media to achieve pedagogical goals. It is a process that should be fulfilled by media education, shaping the recipients' conscious reception of content broadcast by the media. An equally important issue is the use of media for the development of pedagogical activities at all stages. Gębalska-Berekets states that the model of media education should shape competence in their use, but also using them as a didactic tool [Gębalska-Berekets, 2013, p. 87]. As Karolina Ditrych notes in foreign language classes, teachers meet with the lack of this kind of gap. That is why, students do not participate in classes actively as they only repeat information that is contained in didactic text. However, the competence to speak in a foreign language is a determinant that influences the development of other language skills. Their main and fundamental goal is 
to develop skills for effective communication in a foreign language [Ditrych, 2012, p. 19].

\section{EDUCATIONAL FUNCTION OF THE MEDIA}

The attempt to describe the functions of mass media is not only to understand their characteristic features, directions of impact, but also to define and indicate their exceptional character among other means of social communication. The functions of mass media are understood as activities, tasks, relations, mutual dependencies, and even positions or duties. The authors of the Dictionary of Media Terminology define them as "at least the tasks to be performed by them, the goal they should achieve, or the result of their actions" [Pisarek, 2006, p. 62]. While trying to categorize the functions of mass media, it is worth taking into account their fundamental division into their desired functions and undesirable (dysfunctions) ones, whereas the desired functions or the lack of them, may be both on the sender and the recipient side, and at the same time they can be in convergent or divergent communication processes. $\mathrm{H}$. Lasswell, as one of the first scientist, was making theoretical considerations on the functional dimension of mass media and mass communication, claiming that social communication functions are a prerequisite for maintaining a society's existence, integration, continuity and social order, with the reservation that mass communication can also reveal dysfunctional consequences. The main functions of mass media defined by Lasswell referred to [Lasswell, 1948, pp. 32-51]:

- supervision of the surrounding;

- correlation of the group reactions in a society on its surroundings;

- transmission of cultural heritage.

D. McQuail combined the hypotheses of H. Lasswell, C. R. Wright's achievements as well as the results of his own research and proposed a typology of the functions of mass media in a society [McQuail, 2007, pp. 111-112]:

- Information function.

- Correlation function.

- Continuity function (heritage transmission).

- Entertainment function.

- Mobilization function.

M. Mrozowski in his review of the typology of functions of mass media and mass communication also draws attention to the catalog of functions formulated in 1948 by P. F. Lazarsfeld and R. K. Merton. This typology is perhaps less important from the point of view of these considerations, however, it is an important complement to the categorization of mass media functions. The classification of Lazarsfeld and Merton recognized the functions of the media not so much from the perspective of their tasks as from the consequences of their operation and it consisted of two functions and one dysfunction. They include the following [Mrozowski, 2001, pp. 114-115]:

- The function of assigning status - associated with the focusing of social attention and giving importance to public issues, people and organizations.

- The function of strengthening social norms - mass media reduce the discrepancy between private and public morality, strengthening the norms and values on which public morality is based.

- Addiction dysfunction - based on the progressive addiction of recipients to mass communication, which can absorb more and more time, is the result of replacing direct contact with reality with artificial and superficial one, and participation in social life is replaced by passivity and apathy.

In modern typologies, there are also other functions of mass communication media, such as persuasive (propaganda), cultural or educational ones. 
The educational function of mass media includes, to some extent, some of the previously mentioned functions. It is based on providing information about the surrounding world, presenting facts that enable shaping knowledge, showing the truth, communicating content that shapes skills and competences. From this point of view, modern mass media carry out an important task of teaching the recipients about the world. The educational function, however, refers not only to providing information, as information deprived of commentary and embodiment in a certain context (and thus mass communication without a correlation function) would be worthless and useless to many recipients, as they would not be able to make proper use of it. This educational function goes far beyond using the means of mass communication in pedagogy and school education. The impact of mass media in this regard is rather a part of the concept of long life learning, because it focuses on the, mature, well developed and shaped recipient.

The proper definition of mass media functions reflects the effects of research on the use and satisfaction from the media. The traditional approach of these studies dealt with the impact of mass media on recipients in its direct form, trying to answer the question: what do mass media do with people, or how they shape them, change and educate them. A more recent approach reverses the problem, what do people do with mass media and how do they use them? This research perspective, according to T. Goban-Klas, is most marked in two intensively practiced fields of study: in the studies of the so-called uses and gratifications and in the socialization research of mass media functions. The basic assumptions of the theory of uses and gratifications are as follows [Goban-Klas, 1999, p. 253]:

- The choice of media and media content is generally rational and calculated for certain specific purposes and satisfaction (the audience is therefore active and its creation can be explained logically),

- Members of the audience are aware of their needs in relation to media that arise from personal (individual) and social (shared) circumstances, and can express them through their motives,

- In general, usability is a more important factor in shaping the audience than aesthetic or cultural factors,

- All or most of the factors shaping the audience (motives, perceived or received benefits, media choices, social variables) are generally measurable.

\section{MASS MEDIA AND NEW MEDIA IN GLOTTODIDACTICS}

An interesting issue in the context of language education, especially of the younger generation, is the use of audiovisual text in television programs. This situation is important even when the teachers themselves do not use audiovisual instruments in the glottodidactic process. As Elżbieta Gajek observes, a visual text allows the characterization of a given person or situation. The information conveyed in a specific cultural context that illustrates the verbal message in a foreign language by means of a visual text is more precise. At the same time, the level of perception involved in reading the foreign language text while watching television contributes to a greater knowledge of the language. A film or a program is a motivating factor for people to absorb it, because it is interesting for the viewer who focuses on it, wanting to get as much information as possible, while at the same time raising the level of their linguistic competence [Gajek, 2009, p. 108].

An audiovisual text is used in practice in the process of incidental learning. It consists of focusing on the content of the subtitles presented in the native language. This is due to the fact that in the initial period of the educational process, phrases commonly found in a foreign language may pose some difficulties for the student. However, along with the progress in understanding of the content of the spoken language, the meaning of subtitles is decreasing, and the competence in the field of understanding is becoming 
more natural. In another model, an audiovisual text can be effectively used in the process of conscious science. This happens when the viewer is interested in a movie, an actor or a program, and watches the program many times. In this way, the learner remembers phrases, entire sentences, the sound of actors' or teacher's accent. In this situation, he or she can also analyze comparatively the content of the subtitles with the original text that had been seen before [Gajek, 2009, p. 109]. The mass media, which currently use modern technologies, are commonly used in the process of educating the entire society as well as the particular communities functioning in it. The most important meaning in this area is primarily the Internet network. It dynamically enters the educational system at all levels of education. It also applies to foreign language teaching, which takes place outside the institutional model. In language schools, internet communicators, social networking sites as well as "virtual classes" are used. A modern man has the opportunity to develop his/her language skills without leaving home. Also, the public education system gradually begins to meet the standards of civilization, which refers to modern technologies.

In everyday practice of foreign language teaching in primary schools, middle schools, secondary education and in higher education institutions, information technology has become a common didactic tool [Klejnowska-Borowska, 2013, p. 285]. Especially in higher education institutions, lecturers use e-learning platforms, treating them as an integral component of traditional classes. Foreign language teachers can use any of the materials available on the Internet. These include websites, YouTube website, online forums, various types of interactive platforms [Molga, 2015, p. 141].

The teacher must be fully aware that the application of modern technologies as didactic instruments does not bring the desired effects if it is not based on a well thoughtout methodical process. First and foremost, it is necessary to make a change in all aspects of teaching, and therefore broadly understood educational philosophy. Foreign language teachers themselves, and also the school establishment must create conditions that enable the mastery of new technology use by teachers, but also the schools should be prepared to assess teachers' competences in this area. If the person conducting the classes does not have adequate knowledge and practice, then he/she is more willing to return to traditional didactic forms. Currently, the teachers of foreign languages have OHP projectors, allowing multimedia presentations, CD and DVD players or interactive boards. However, at present, the Internet has become the dominant methodological tool used in foreign language teaching. A statement that the Internet has contributed to the revolution if foreign language teaching can be posed.[Knapkiewicz, 2015, p. 20]. A computer with the Internet connection is becoming an effective instrument that allows real-time access to authentic and, most importantly, current materials that are created by all Internet users. Thus, it gives teachers the opportunity to use educational solutions in any didactic or cultural context, or finally in relation to the desired content [Gajek, 2000, pp. 118-119]. The dynamic progress of knowledge in the area of all scientific disciplines causes a fact that the knowledge acquired during studies "is getting older". This means that people must constantly update their knowledge to create a high degree of professionalism throughout their professional life [Gajek, 2008, p. 37]. New technologies have been introduced into the catalog of methodological instruments of foreign language teaching relatively recently, but they have immediately contributed to the effectiveness of foreign language teaching process. It is not only an adaptation of the technological possibilities noticed for the discussed needs, but it is also an integral element of the civilization development. In addition, the use of multimedia and audiovisual instruments contributes not only to a significant improvement of foreign language teaching, but also to their greater attractiveness. In this way, the knowledge transferred and the competencies shaped are more willingly absorbed and comprehended by the students. The catalog of didactic instruments, which are based on modern technologies, gives the teacher the opportunity to choose the ones that are most effective in his/her opinion [Grabara, Wilk, 2013, p. 99]. The most commonly used media classification, included in education- 
al activities, is divided into [Zarzycka, 2014, p. 324]:

- auditory media, which affect the recipient via the ear canal, which is used while listening to music, radio, $\mathrm{mp} 3$ files,

- visual media, which affect the viewer through the visual channel, due to the use of the image, and a moving image such as a movie,

- audiovisual media, which affect the recipients via their sensory channels.

The presented classification is only an example of the multiple divisions available today. Along with the dynamic development of computer and IT techniques that apply to foreign language teaching, there is also a need to redefine the definition and function of mass media in the educational area. Undoubtedly, however, the Internet network and mobile devices enrich the process of foreign language teaching. One of the examples of effective connection of the didactic process with the Internet network in the foreign language learning process is e-learning. This form of educational platform is a virtual work environment used by students and teachers. The teaching process, as practice shows, gives almost unlimited possibilities in constructing goals, and at the same time activating the participants of this form of classes. E-learning has, at the same time, become a requirement of today's times [Grabara, Wilk, 2013, p. 100]. E-learning is a form of teaching in which modern computer and multimedia technologies as well as an internet network are used. In other words, it is a kind of teaching and learning process intensively supported by computers or modern mobile devices that have an internet connection.

The discussed model allows actions in the field of decentralization and de-normalization of didactics of foreign language teaching. Free, unrestricted access to the learning platform gives the opportunity for students and teachers to implement the program in any place and time. E-learning can be successfully used to conduct courses, but also to study at higher education level, without having to be physically present in the lecture hall, the latter being transferred to the virtual space [Piecuch, 2010, p. 234]. The didactic method using the Internet and computer network referred to as CALL (Computer Assisted Language Learning), or computer-assisted foreign language learning, does not mean the rejection of the teaching instruments used so far. It contributes to the simultaneous expansion of their educational possibilities and the implementation of many novelties connected with the state of the art technology. Undoubtedly, this method combines the possibilities of the Internet and modern media resources such as graphics, text, animation and video. In this way, a series of competences like speaking and listening are combined, they are integrated with the image, creating conditions comparable to the real-life situation. Writing, reading, listening and speaking skills can be combined in one exercise. On the other hand, the Internet network becomes a tool for effective communication between all participants of the learning process. The student himself interested in acquiring more information in a foreign language has the opportunity to search for it in virtual space [Barańska, 2004, p. 82]. Multimedia tools are a norm in today's school, which also affects the dynamics of changes in didactic activities. The twenty-first century is, according to Krzysztof Pytel, a period when modern technologies are of great importance in education. The integration of school goals and such instruments is an important task, as Pytla suggests, for both teachers and students in achieving success in the educational process. The memory teaching method in today's realities does not meet the assigned tasks. Teachers also face the necessity of self-education in this area, which is a condition for providing modern forms of knowledge to students, but at the same time raising their own potential [Pytel, 2010, p. 57]. Skrzydlewski believes that didactic tools, which use a moving image, language or sound are an integral element of the modern education process. They are used in the teaching process on a large scale. The author also believes that digital technologies are able to integrate as many information carriers as possible in one place [Skrzydlewski, 1997, p. 80] . R. Gozdecka, on the other hand, emphasizes that innovative goals must focus on many important areas. In the author's opinion, the following areas are of particular importance: the construction of classes during which 
the audiovisual means are used in a creative and, what is even more important, effective way. She assigns particular importance to computers that effectively influence the development of competences based on students creative thinking. Teachers themselves also have the opportunity to participate more effectively in working with talented pupils, and modern didactic technologies allow them to continually improve the methodological structure of classes [Gozdecka, Weiner, 2013, p. 13].

At this point, it is necessary to define the notions of didactic means that can be found in the literature of the subject. Their number and innovative applications contribute to a clear optimization of the learning process and learning outcomes [Okoń, 2003, p. 275]. All actions aiming to achieve teaching goals using modern technologies in a natural course of things require the modern teacher to use both programs and applications that are increasingly being used in education. It is also indispensable to look for new IT tools that are applicable in the didactic process [Czekaj-Kotynia, 2013, p. 77].

The contemporary publishing market offers wide a choice of many IT teaching instruments for the teachers. The users of this market sector meet the educational needs, being aware of the roles, objectives and tasks of the technologies provided. It can be clearly stated that today's school multimedia tools are already a recognized and desirable standard. The process of the digitization of the lesson begins already in the consciousness and mentality of the teacher himself/herself. It is he/she who sets the direction of the class and skills that will be developed while using a computer, and which require the use of traditional methods. For example, an interactive whiteboard can be used during a lesson, and a homework task via the Internet can be assigned. In this respect, one cannot overestimate the role of modern didactic technologies, which despite their innovative character, are still only an instrument in the hands of the teacher of the subject [Jaros, 2017, p. 57].

Modern teaching technologies are an attractive form of teaching as far as the content delivery is concerned, but at the same time while using the right stimuli, they increase the effectiveness of the teaching and learning process, through the appropriate adaptation to the current needs and possibilities of the student. They are an interesting form of individualization and personalization of the educational message, as it allows both listening and watching. At the same time, students have the opportunity to use many types of educational games, use thematic websites, quizzes, tests which can be solved on the Internet. Another didactic tool in foreign language teaching is connected with computer programs that allow the shaping of all language competences, and thus, the teachers have the opportunity to check the progress in learning process of their learners. Students create their own language portfolio in the form of a catalog of words and phrases, while the teachers act as inspectors and guides in this process. Multimedia solutions allow students to learn during extracurricular activities, as well as to contact people who speak the same language as their mother tongue. A very effective way in foreign language teaching is the implementation of projects that is supported by information technology. It is an ideal way to work together in a group, when a foreign language is used in parallel to the core curriculum and, and what is very important, it gains a practical dimension, increasing the efficiency of the teaching process [Gruz, Pabianczyk, 2016, p. 5].

Modern didactic methods can also be used as a supplement or even a basic element in the creation of author's programs of foreign language lessons. Despite the undoubted advantages, modern didactic methods are often perceived as tools that are a universal way of achieving success in the teaching process. Stereotypically, classes with a computer or an interactive whiteboard look like a simple and easy way to transfer the teaching material. However, at the same time, it cannot be forgotten that they are only a modern catalog of teaching resources, but still fulfill such a function, similarly to a textbook or a traditional paper exercise book. The technology fulfills only the function of an instrument of achieving the assumed goals. However, if the goals are formulated incorrectly or incorrectly implemented, then they too will prove unreliable and ineffective. 
They cannot be treated as a kind of a "gadget". What is important, IT tools in foreign language didactics, also have a large group of critics. However, the latter are a minority among authors investigating this issue [Jaros, 2017, p. 6].

The progress of glottodidactics and the progress of modern didactic tools cause the fact that learning foreign languages is becoming more and more effective and interesting for the student and the teacher at the same time. In a specific "canon" of foreign language teaching, it is assumed that a success can be noted when the student reaches the following competences: grammar, listening comprehension, speaking comprehension, writing comprehension and reading comprehension [Szewczyk] , 2012, p. 137].

Therefore, the traditional grammar - translation method of teaching foreign languages, which used to be commonly considered to be the best, is currently being assessed as less and less effective one.

The superiority of teaching methods using mass media and multimedia is manifested in the fact that they are associated more with entertainment than with an obligation or a chore. Thus, mass media based teaching is being widely promoted in educational institutions and other places where foreign languages are taught and where the computers, Internet networks, multimedia boards and other electronic information carriers are implemented and as common as traditional and new means of communication.

\section{REFERENCES}

BARAŃSKA A. (2004), Ewolucja CALL - nauka języków obcych z wykorzystaniem komputera, „Języki Obce w Szkole", Nr 1.

CZEKAJ-KOTYNIA K. (2013), Nowoczesne metody dydaktyczne w procesie kształcenia, Instytut Nauk Społeczno-Ekonomicznych, Łódź.

DITRYCH K. (2012), Nauka komunikacji na lekcji języka obcego, „Językoznawstwo”, Nr 1.

GAJEK E. (2009), Edukacyjne znaczenie napisów w tekście audiowizualnym, „Przekładaniec. A Journal of TranslationStudies", $\mathrm{Nr} 20$.

GAJEK E. (2000), Komputery w nauczaniu języków obcych, [w:] Nauczanie języków obcych w zreformowanej szkole, Instytut Badań Edukacyjnych, Warszawa.

GAJEK E. (2008), Edukacja językowa w społeczeństwie informacyjnym, Wydawnictwo Instytutu Lingwistyki Stosowanej Uniwersytetu Warszawskiego, Warszawa.

GARWOL K. (2017), Rola mediów społecznościowych w edukacji-tan obecny i perspektywy rozwoju, „Dydaktyka Informatyki", Nr 12.

GAWROŃSKI S. pod red. (2011), Dydaktyka dziennikarstwa. Opinie i postulaty, Wydawnictwo Konsorcjum Akademickie, Kraków-Rzeszów-Zamość.

GAWROŃSKI S., POLAK R. (2010), Dziennikarstwo i komunikacja społeczna - nowe wyzwania, Wydawnictwo Konsorcjum Akademickie, Kraków-Rzeszów-Zamość.

GĘBALSKA-BEREKETS A. (2013), Znaczenie i rola mediów we współczesnej edukacji społeczeństwa informacyjnego, [w:] Media w edukacji, A. Rogulska, Fundacja na rzecz dzieci i młodzieży, Siedlce.

GOBAN-KLAS (1999), Media i komunikowanie masowe, Wydawnictwa Naukowe PWN, Warszawa.

GOZDECKA R., WEINER E. (2013), Profesjonalizm edukacji muzycznej. Propozycje dla zmieniającej się szkoły, Wydawnictwo Uniwersytetu Marii Curie-Skłodowskiej, Lublin.

GRABARA M., WILK M. (2013), Elementy e-learningu w nauczaniu języków obcych, „Prace Naukowe Akademii im. Jana Długosza w Częstochowie. Studia Neofilologiczne", Nr 9.

GRUZA D. , PABIAŃCZYK A. (2016), Język polski 2.0 - zastosowanie nowoczesnych technologii w nauczaniu języka polskiego, Fundacja Edu\&More, Warszawa.

ItOWIECKI M. (2003), Krzywe zwierciadło. 0 manipulacji w mediach, Gaudium, Lublin.

JAROS I. (2017), Technologie cyfrowe we wczesnej edukacji językowej, „Języki obce w szkole”, Nr 2.

KAWKA E. (2015), Komunikowanie wizualne a nauka o mediach - współczesność i perspektywy, "Media i Społeczeństwo", Nr 5.

KLEBAN M. (2014), Pakiet metodyczny dla nauczycieli języków obcych Il etapu edukacyjnego, Ośrodek Rozwo- 
ju Edukacji, Warszawa.

KLEJNOWSKA-BOROWSKA M. (2013), Rola internetu w nauczaniu języków obcych - perspektywa nauczyciela, [w:] Media w edukacji, A. Rogulska, Fundacja na rzecz dzieci i młodzieży, Siedlce.

Kluczowe dane dotyczące nauczania języków obcych w szkołach w Europie. Raport Eurydice,(2012), Urząd Publikacji Unii Europejskiej,Luksemburg.

KNAPKIEWICZ M. (2015), Od zasobów gramofonowych do zasobów internetowych, „Języki obce w szkole”, $\mathrm{Nr} 4$.

KOMOROWSKA H. (2005), Metodyka nauczania języków obcych, Fraszka Edukacyjna, Warszawa.

Kompetencje kluczowe w uczeniu się przez całe życie. Europejskie Ramy Odniesienia, (2007)Urząd Oficjalnych Publikacji Wspólnot Europejskich, Bruksela.

LASSWELL H. (1948), The structore and function od communication in socjety, w: L. Bryson (red.), The communication of ideas, Harper, NowyJork.

LAZARSFELD P. F., MERTON K. R. (1948), Mass Communication, Popular Taste and Organized Social Action, W. L. Bryson (red.), The Communication od ideas, Harper \& Row, NowyJork.

LEPA A. (2000), Pedagogika mass mediów, Archidiecezjalne Wydawnictwo tódzkie, Łódź.

LEWICKA-MROCZEK E., KRAJKA J. (2011), Kompetencje uczenia się i kompetencje informatyczne jako metakoncepcje w procesie uczenia się języka obcego - o rozwijaniu kompetencji kluczowych w nauczaniu dzieci, "Poliglota", Nr 1 (13).

ŁOŚ E., RESZKA A. (2010), Metody nauczania stosowane w kształtowaniu kompetencji kluczowych. Języki obce, podręcznik metodyki operacyjnej, Wydawnictwo Naukowe Wyższej Szkoły Ekonomii i Innowacji, Lublin.

MCQUAIL D. 2007, Teoria komunikowania masowego, PWN, Warszawa.

M-learning czyli @ewolucja w nauczaniu, Think Global, Warszawa.

MOLGA A. (2015), Platformy e-learningowe - serwis internetowy o profilu dydaktycznym, „Dydaktyka Informatyki", $\mathrm{Nr} 10$.

MROZOWSKI M. (2001), Media Masowe. Władza - rozrywka - biznes, Aspra JR, Warszawa.

NĘCKI Z. (1996), Komunikacja międzyludzka, Wydawnictwo Profesjonalnej Szkoły Biznesu, Kraków.

OKOŃ W. (2003), Wprowadzenie do dydaktyki ogólnej, Wydawnictwo Akademickie Żak, Warszawa.

PIECUCH Ł. (2010), Platformy e-learningowe, "Edukacja-Technologia-Informatyka", Nr 2.

PISAREK W. pod red. (2006), Słownik terminologii medialnej, pod red. W. Pisarka, Universitas, Kraków.

PYTEL K. (2010), Technologia informacyjna w edukacji,„Edukacja-Technika-Informatyka, Nr 2.

RETTER H. (2005), Komunikacja codzienna w pedagogice, Gdańskie Wydawnictwo Psychologiczne, Gdańsk.

Rozporządzenia Ministra Edukacji Narodowej z dnia 30 czerwca 2006 roku w sprawie standardów kształcenia nauczycieli w kolegiach nauczycielskich i nauczycielskich kolegiach języków obcych ( Dz. U. z 2006 roku, nr 128, poz. 897 ).

Rozporządzenia Ministra Nauki i Szkolnictwa Wyższego z dnia 17 stycznia 2012 roku w sprawie standardów kształcenia przygotowującego do wykonywania zawodu nauczyciela ( Dz. U. z 2012 roku, poz. 131 ).

SKRZYDLEWSKI W. (1997), Media - narzędzia intelektualne, [w:] Media a edukacja, eMPI2, Poznań.

SZEWCZYK A. (2012), Technologie multimedialne wspierające dydaktykę języków obcych, „Dydaktyka Informatyki", $\mathrm{Nr} 7$.

TARGOŃSKA J. (2009), Wiedza czy umiejętności? Czego potrzebuje dobry nauczyciel języka obcego?, [w:] Nauczyciel języków obcych dziś i jutro, red. M. Pawlak, A. Mystkowska-Wiertelak, A. Pietrzykowska, Poznań-Kalisz.

TRAWIŃSKI M. (2009), Przygotowanie nauczycieli języków obcych do wyboru i oceny programów nauczania, [w:] Problemy współczesnej dydaktyki języków obcych, red. M. Pawlak, B. Wolski, Polskie Towarzystwo Neofilologiczne, Poznań-KaliszZalecenia Parlamentu Europejskiego z dnia 18 grudnia 2006 roku w sprawie kompetencji kluczowych w procesie uczenia się przez całe życie(2006/962/WE).

WIESNER W. (2005), Komunikacja dydaktyczna na lekcjach wychowania fizycznego a poziom autorytaryzmu nauczycieli, Akademia Wychowania Fizycznego we Wrocławiu, Wrocław.

WRIGHT C. R. (1959), Mass Communication. A sociological Perspective, Random House, NowyJork 1959.

ZARZYCKA G. (2014), Media w nauczaniu języków obcych. Koncepcje teoretyczne i wybrane rozwiązania teoretyczne, „Acta UniversitatisLodziensis. Kształcenie Polonistyczne Cudzoziemców”, Nr 21. 